Cretiu, A.-E. (2021). Politeness and the Art Criticism Discourse. Scientific view on the modern problems of cultural heritage and arts in the context of social development. Klironomy, 1 (1), 163-180. Hlučín-Bobrovníky: "Anisiia Tomanek" OSVČ.

Crețiu, A.-E. (2021). Strategii ale politeții în discursul criticii de artă. Scientific vien on the modern problems of cultural heritage and arts in the context of social development. Klironomy, 1 (1), 163-180. Hlučín-Bobrovníky: "Anisiia Tomanek" OSVČ.

DOI: $10.47451 / \operatorname{art} 2021-04-002$

EOI: $10.11249 /$ art2020-04-002

The paper is published in Crossref, Internet Archive, Google Scholar, Academic Resource Index ResearchBib, JGate, ISI, CiteFactor, ICI, eLibrary databases.

\title{
Politeness and the Art Criticism Discourse
}

\section{Abstract:}

Art criticism usually manifests itself in such written genre-texts as art reviews. When producing such a text, the critic finds himself/herself in a position of the interface between the general public and the artist, and, consequently, between the general public and the work of art. While, on the one hand, the critic has to remain true to his/her role as a guide to mediating understanding and appreciation of the works of art by the audiences, meanwhile bringing efficient/effective suggestions for the artists, on the other, the critic also needs to be a master of good writing in the use of the most effective discourse strategies. These include the application of the most relevant politeness principles for the sake of perpetuating good communication throughout the art world. The present study aims to discern the mechanisms of utilizing those principles in art criticism, in direct relationship to how works of art are (negatively) evaluated by the critics, who may balance between remaining polite and becoming utterly/straightly impolite, for the sake of truth.

Keywords: art, art criticism, the pragmatics of politeness, discourse strategies.

Anda-Elena Creţiu Conferențiar universitar, Doctor în domeniul filologie

Departamentul Discipline Teoretice Facultatea de Arte Decorative şi Design 
Universitatea de Artă şi Design

Cluj-Napoca, România

E-mail: anda.cretiu@uad.ro

\section{Strategii ale politeții în discursul criticii de artă}

\section{Requmat:}

Critica de artă se produce de obicei în recenzii de artă. În scrierea unui astfel de text, criticul se manifestă ca o interfață între public și artist și, în consecință, între public și opera de artă. În timp ce, pe de o parte, el trebuie să rămână fidel rolului său de ghid ce mediază înțelegerea și aprecierea operelor de artă de marele public, aducând totodată sugestii relevante artistului, pe de altă parte, criticul trebuie să fie un maestru al scrisului, capabil să utilizeze cele mai eficiente strategii discursive. Acestea includ și aplicarea unor principii ale politeții, cu rolul de a asigura perpetuarea unei bune comunicări în lumea artistică. Studiul de față dorește să distingă acele mecanisme de aplicare a principiilor politeții în critica de artă, mecanisme ce se află în directă legătură cu evaluarea (în special în cazul aprecierilor negative) făcută de critic, care poate pendula între a rămâne politicos și a deveni de-a-dreptul nepoliticos, de dragul adevărului.

Cuvinte-cheie: artă, critică de artă, pragmatica politeții, strategii discursive.

\section{Introduction}

The role of art criticism (which is nowadays re-named art appreciation) is perceived to be an interface between the public and the work of art. This role has become more and more obvious beginning with the first part of the 20th century, and with the first attempts to modernize art. People found themselves baffled in front of the new works of art and could not make sense out of what they were seeing anymore. They searched for some guidance to understanding what was going on in the art world, to what a work of the new art meant and to how valuable that was. The need for specialized guidance has become even more obvious these days since contemporary art is so multi-faceted and complex.

There are numerous schools of criticism, based on just as many doctrines, but they all have in common the same desire to mediate between the work of art and the general (and sometimes even specialized) public and to boost communication within the art world. No matter whether art is viewed purely philosophically, or mainly historically, or sociologically and psychologically, the whole enterprise proves to be "a coat of many colors" (Iacob, 2019). It is also a fact that there are a great many personal styles of 
criticizing art as well as of writing styles. Some critics tend to be positive and polite; some prefer to be blunt and/or true to themselves. Many can grade their critical discourse and use all the possible discourse strategies to offer their readers a complex view of the art under their scrutiny.

The purpose of the present study is to find the ways in which art criticism works, especially in the case of negative appreciation of the works of art, that is, to distinguish the mechanisms the critic utilizes in order to send the reader his/her exact evaluation of those works. This research focused on whether and how exactly the critic chooses to remain polite or not when criticizing a certain work. For that, a number of art review texts (around 35, from different art magazines - Art in America, Artnews, Artforum International and newspapers possessing an art column - The Telegraph) have been considered. The research applied a pragmatics methodology, starting from the classical Gricean maxims and Leech's politeness principles, rediscussed in Brown and Levinson and in Thomas, also studied by Rehm and André and by Myers in scientific writing. The central concept adopted here is that of face management. The study focused on how the critic deals with it in different circumstance and for different purposes. Some similarities between the criticism discourse and those of advertisement and propaganda have also been distinguished, along some coordinates mentioned in Zdrenghea.

\section{Art criticism, advertisement, and propaganda - some discourse similarities}

To establish some functional channels to communicate both within and without the artistic discourse community, art critics devised several genres (and texts), out of which maybe the most effective one appears to be the art review. The discourse strategies involved in creating efficient art reviews reveal the fact that, just as in advertisement, the public is perceived as a target. "The language used by advertisers indicates that they think of people as targets. In advertisements, they use language which is subtle and cajoling [...]" (Zdrenghea, 2004, a).

This does not mean that the audiences of both the works of art and art criticism are the only target of such texts. The artists themselves are also part of the communication process; they may relate to art criticism in different ways: they may find some guidance in what is being written about their works, or they may feel re-assured, flattered, or, on the contrary, they may be offended and feel under attack. Hidden agendas sometimes dictate the type of discourse employed by art criticism, and just as "advertising is a versatile and sophisticated form of social communication" providing 
"the symbolic tools for the circulation of everyday meaning" for "presenting, suggesting and reflecting an unending series of possible comparative judgments. Controversial or not" (Zdrenghea, 2004, a), so will art criticism texts (art reviews) make use of all necessary strategies to reach their goals.

Appealing to people's desire to achieve a higher status can also be exploited by art critics, just like by advertisers. "Owning and using expensive products is one of the most direct ways to improve one's image and status" (Zdrenghea, 2004, a). The art critic may find a way to prompt an art collector to buy a certain expensive work of art whose ownership would prove his/her high social status and, obviously, his/her exquisite taste and knowledge of art.

Art criticism texts also present several similarities with the propaganda discourse in what the channels and methods of achieving their communicative purposes are concerned. Manipulation plays an important role in this complex process of communication. It may take the form of stereotype, tautology, cliché, and a null informational content (Zdrenghea, 2004, b). Also similar to propaganda language may appear the frequent use of some strange syntax and vocabulary, and its preference for nominal constructions manifested as "an interest no so much for the noun but for the opportunities to incorporate in this class non-specific manifestations of adjectival, pronominal or verbal nature." (Zdrenghea, 2004, b). So many times, the discourse of art criticism makes use of such devices, for different reasons and to different purposes. It was even given a name: Artspeak (also known as International Art English) (Crețiu, 2014).

Thus, art criticism discourse manifests several similarities with both advertisement discourse, and propaganda discourse, since they all work to influence people, to make the public believe certain things, in certain ways, to certain purposes. Up to a point, their mechanisms are also similar as well as the expected results: an advertised work of art appeals to people's desire to own that work, manipulating them to believe that the work is of certain value, all these with not necessarily negative connotations.

\section{The importance of politeness in writing}

However, the art critic needs to write as responsively as possible, trying to find a balance between the public for whom s/he is writing, who has a right to be well advised, and the artists-creators, who also need good, well-informed advice and who do not enjoy criticism attacks. The art critic has to become a master of using politeness strategically, 
developing all the necessary linguistic-rhetorical-pragmatic-discursive strategies to keep that balance and ensure communication meanwhile remaining true to himself/herself.

A question that somehow finds itself in the middle of this process of criticizing art is probably how charitable or kind is the art critic supposed to be when criticizing a work of art? Philosopher Daniel Dennet (Dennet, 2013) reformulates the strategy suggested by the social psychologist and game theorist Anatol Rapoport, and proposes four steps to arguing intelligently and avoiding the tendency to caricature a possible opponent:

1. You should attempt to re-express your target's position so clearly, vividly, and fairly that your target says, "Thanks, I wish I'd thought of putting it that way.

2. You should list any points of agreement (especially if they are not matters of general or widespread agreement).

3. You should mention anything you have learned from your target.

4. Only then are you permitted to say so much as a word of rebuttal or criticism.

Most probably these Pollyannaish (positive) principles may prove quite hard to follow by art critics in many circumstances. However, it is common knowledge that people tend to remember and respond to positive criticism better rather than to negative criticism, and using the former type may also prove beneficial for the advancement of communication.

The now already classic pragmatics of politeness developed by Brown and Levinson (1987) referred mainly to oral exchanges in conversations. However, their notions and strategies may just as well be applied to written texts, especially if these are seen as written dialogues between writers and readers, with the readers as a necessary presupposition, rather than acting in the imagined dialogue. In his study on the pragmatics of politeness in scientific articles, Greg Myers (Myers, 1988) also argues that the above model could be extended to some genres of written texts, despite the difficulty of not having a definite addressee and that of defining relevant cultural variables. He focuses on the ambivalent relationship established between writers of scientific articles and their readers and between writers of such articles as researches and other researchers. In this two-facetted relation, several FTAs (face-threatening acts) are performed, which necessitate different politeness strategies for redressing them. The concept of "face" (borrowed by Brown and Levinson from Erving Goffman, 1967) and that of the size of imposition account, in Myers's opinion, for otherwise unexplained aspects of writing scientific articles. 
Rehm and André (Rehm \& Andre, 2005) focused on how politeness is expressed using gestures, which are used by communicators to enhance the verbal manifestations of politeness strategies. Adopting Walker et al. (1997) approaches to implement politeness strategies, they made a corpus study distinguishing some politeness strategies divided into four categories and accompanying many verbal instantiations. For example, direct strategies are conveyed by direct uttering of threats, without any redress. Approval-oriented strategies are related to the positive face needs of the addressee and may consist in conveying interest through complimenting and use of intensifying adjectives, in claiming common knowledge through "white lies", and such phrases as "sort of", "in a way", or through the use of jokes, etc. Autonomy-oriented strategies include making minimal assumptions while using such hedges as "I think" and "kind of" and minimizing threat through the use of euphemisms and such quantifiers as "a little" and "just", etc. Off-record strategies are related to violations of the maxims of relevance (through the use of associations and hints), quantity (through exaggerations like "always"), quality (through the use of irony and rhetorical questions), and manner (through ambiguity and elliptical utterances). The two researchers found that the verbal acts of politeness are strengthened by the use of gestures: iconic and deictic gestures are mainly used to emphasize direct criticism, while metaphoric gestures are employed in off-record strategies. They also quote McNeill, who noticed that iconics and deictics are attributes of narrative contexts, while metaphorics tend to occur in non-narrative contexts.

Thus, as previous research of the concept and the mechanisms of politeness suggests, there is a certain "know-how" an art critic should possess, starting from an intelligent argumentation, then considering the face management of both the criticized artist, and of the reader when dealing with inevitable face-threatening acts. The discourse strategies involved in these processes are complex and various and the writer needs to make the most effective linguistic choices, since there are no other extralinguistic possibilities of expression (mimics, gestures) to strengthen or smoothen the written words.

\section{Art reviews as a genre of the critical discourse}

In what follows we shall try to distinguish some regularities in the art criticism discourse (especially in art-review writing), along the same coordinates. The art review is probably the most complex, useful, and efficient genre of the artistic discourse community because it serves both the purposes of the artists themselves, as the most 
relevant members of the artistic discourse community, and the purposes of the general public, for whom art is produced, and without whose interest artists could not survive. Art reviews are rather short texts appearing in magazines (more or less specialized in art), (academic) journals, newspapers, radio and TV broadcasts, etc.

Their specific communicative purposes are: to inform about an artistic event, to promote such an event and the artist, to competently describe, interpret, and especially evaluate (or judge) an exhibition (and the exhibited works), to persuade the readers to accept the offered interpretations and evaluations and therefore to go and see the exhibition for themselves and (why not?) buy some of the works, to educate the public taste, to guide the artists, to establish a market value of the reviewed works and artists (Dennet, 2013). It seems that, despite the small size, such a text has a lot of work to do.

The writers of such texts are usually art critics. Art historians, journalists, artists themselves, philosophers (art aestheticians and theorists), professional writers who happen to write art reviews may also be generically considered art critics. The art critic finds himself/herself halfway between artists and their public. Since, for many people, art doesn't seem to "speak for itself", especially in these post-postmodern days, the critic has to act as a mediator between the two and therefore has a two-fold responsibility; despite being a member of the artistic discourse community, she/he has to remain true to himself/herself and act responsibly when offering the audience guidelines for interpreting artworks, several possible interpretations and value judgments (positive or negative evaluations) of the reviewed works. Good criticism always presupposes offering evidence for the interpreted aspects and applying certain criteria in judging art (these criteria are rather implicit than explicit, and are suggested rather than clearly stated in art reviews, as opposed to art theory).

The audience for whom an art critic reviews exhibitions is mainly the general public, consisting of educated, experienced readers, not necessarily art experts, but possessing a certain degree of connoisseurship, or, at least some intuition about art, people who expect to learn something new about art, to see a subject from a different perspective than their own, people who are interested in art but may need a little help to understand and appreciate art, busy art collectors who are considering whether to go or not to see an exhibition and who want to be offered some investment suggestions, and even art specialists and artists themselves who try to get an idea about who and how may judge their art, about what other artists create and what the value of other artists is. 
Thus, the art review genre appears to be the most effective one for art criticism. As a genre, it serves the communicative purposes established by the artistic discourse community: informing about an artistic event, advertising it, analyzing the most important works (describing and interpreting them), evaluation them, persuading, educating. The most important feature of this genre is that it addresses two audiences: first, the general public, then the specialized public; therefore, the writer needs to adapt his/her discourse strategies accordingly.

\section{Discourse strategies of politeness in art criticism}

In fulfilling such a complex job, an art critic has to perform, more often than not, several face-threatening acts (FTAs). Naturally, this happens when negative appreciation is in question. Dealing with them implies good handling of politeness strategies. Depending on whose face is threatened and on the dimension of the imposition, the strategies will address both the positive and the negative face of the audience and the artist.

In Brown and Levinson's approach, any "model person" is endowed with a "negative face" (the person wants to be unimpeded, that is, free) and a "positive face" (the person wants to be approved and appreciated). It seems easy to guess that any artist would like to be well appreciated and loved and not criticized. In fact, the very process of art criticism is now called art appreciation, exactly due to the negative connotation of the term "criticism". Usually, art critics are generous with the artists (especially if they get paid by the galleries hosting the exhibitions) and tend to see the positive aspects, the valuable features of the artworks. However, any responsible critic will balance the artist's negative face (the desire of not being impeded) and his positive face (the desire to be loved and appreciated) with the great responsibility an art critic has toward the public: the correct appreciation of the value of the artworks under scrutiny. The readers, on the other hand, also have a negative face (they want to feel free when interpreting and evaluating works of art, i.e., they do not want to be told exactly what and how to understand and appreciate art), and a positive face (they want to be considered the equals of any art critic, that is, treated as if they possessed the necessary degree of expertise, or at least, connoisseurship, as to understand art.).

Politeness strategies stem from an insightful weighing of the importance the above variables have in a specific FTA: the artist's negative and positive face, the audience's negative and positive face, the generosity an art critic is expected to show the artists, the 
responsibility toward the public. The relative power position a critic finds himself/herself in may also determine the choice of one strategy or the other. Power may be defined as the transformative capacity of agents to affect the course of events. The critic possesses a certain kind of legitimate power of judging other people (evaluating artists' works) and a certain kind of expert power over the audience for whom s/he writes, that is, the critic has the knowledge, the "know-how" the public needs. In the case of some famous and widely listened to art critics we may also speak about referent power, consciously or unconsciously exercised over his/her admirers (Thomas, 1995).

The politeness strategies employed to handle the FTAs toward the artists come into play when negative judgments are made on the artworks and range from performing the FTA without redress to changing the bad into good evaluation (ambivalence).

\section{A. Performing FTA "bald-on-record" (without redressing)}

When performing an FTA without redressing, the art critic has previously weighted upon the artist's needs and the audience's right to be well informed as to the value of the artwork. Since the value of the work is very low, the critic does not feel the need to be polite in any way and acts responsibly toward the public:

Example 1. [...] for its 18 paintings, representing Schnabel's artistic output over the past decade, are irrefutably awful. I'm not sure I have ever seen such overblown yet forgettable paintings in my life.

Example 2: Peter Sarkisian's appalling multichannel mother-and-child-in-acube projection is as close to offensive as this show can get.

B. Hedging/minimizing imposition of negative evaluations

B1. Rhetorical question: the implied negative connotation answer to such a question is avoided by the rhetorical quality of the question:

Example 3. The sheer abundance of the works and their sense of the ridiculous lend a populist appeal to his artistic enterprise, but where does it go from here?

\section{B2. Expressing (personal) hope/skepticism/ regret:}

Example 4. If Dzama hears eBay calling, I hope he doesn't answer. (The critic implies that there is only a small step the artist should avoid to take toward a worse stage of his creation);

Example 5. This survey of new art parodies avantgarde obsessions of the 1970s far more than it makes a case for new ideas. It mostly reflects the 
preoccupations of art school-sheltered youth by and for whom the show is largely made. Let's hope it's not the one we deserve. (The implicature here is that we, the public - a so notice the plural of solidarity - do not deserve such a poor-value art, like the one exhibited by this show);

Example 6. Stripping away the context $[. .$.$] is no small achievement, but$ unfortunately, that's what Gordon did. While he hoped to add narrative power to his formal exploration by drawing on the potency of his source, the work itself felt ponderous by comparison - less an advertisement for the potential of Gordon's art than a demonstration of the strength of Scorsese's.

\section{B3. Minimizing assumption by expressing a false doubt:}

Example (see 1). I am not sure I have ever seen such overblown yet forgettable paintings in my life.

\section{B4. Minimizing imposition by using a 'suggest' verb for evaluation:}

There seems to be a certain dichotomy in choosing verbs when writing about art. There is the verb "to be", on the one hand, used mainly for describing art, or for wellestablished facts and appreciations throughout the history of art, and, on the other hand, there are the "suggest" verbs, used mainly for interpreting artworks, and sometimes for evaluations. They are used to reduce the size of the imposition of personal interpretations and evaluations.

Example 7. [...] but for the most part, it [the show] seems to have little to do with art ... It even seems to trivialize work of established artists...

B5. Hedging by modifiers:

Example 8. With over 50 works, the show felt unwieldy at times... (also notice the "suggest" verb felt);

Example 9. The tearing open of Heidi's stomach at the end of Heidi 2 [a performance] so that Mom can insert a television monitor atop the girl's intestines is a none-too-pleasant sight. Heidi, however, doesn't seem to mind. (also notice the black humor and the 'suggest' verb).

B6. Balancing the negative and the positive (less important) aspects:

Example $10[\ldots]$ expressive gesture and Minimalist geometry remain precariously alive, even as they have been ingeniously assimilated (also notice the modifiers) (in "Weimin Huang...”); 
Example 11. Wayne's talent is real, but perhaps her paintings innards are a little too exposed." (also notice the hedging quantity modifier "a little too") (in "Leslie Wayne ...");

Example 12. For me, the iconography of the piece isn't so interesting - the bling disco death-head thing has been done before in more impoverished variations. The interesting thing is the brazen fetishization and attitude Hirst's done it for real, using real diamonds, real cash. (also notice minimizing assumption through the use of 1 st person suggesting that it is only a personal judgment).

B7. Using minimizing expressions (downgraders, to reduce the size of imposition by a negative evaluation)

Example $13[\ldots]$ and what remains is hypnotic but controlled, yet there persist some loose edges, some prescribed awkwardness, as it were.

a) using neutral attribution of opinion for interpretations and evaluations: Example 14. [...] mouth open in a scream, although whether of pleasure, pain, or protest is uncertain. Likewise, for the viewer, who might also find it unclear how to respond to these dispassionate amoral children caught across the divide between the consciousness of childhood and that of adulthood $[\ldots]$

b) minimizing the "guilt" of one by extending the "guilt" to many:

(given the fact that the artist had recently died, the critic also feels the need to enhance the idea that the evaluation is his own / attributing by the firstperson pronoun; also notice the verb "to suggest", and the hedging adverb "perhaps" trying to minimize the imposition of personal opinion); Example 15. I want to suggest that Huang was caught on the horns of the dilemma that epitomizes the current position of abstract painting, perhaps of all art in this so-called postmodern situation (and it is a recurrent situation rather than a period): how to make something new out of something old [...] (also notice personal attribution of opinion, "suggest" verb, and hedging adverb to reduce imposition) (in "Weimin Huang...");

c) using suggestion (as an indirectness device) for negative evaluation:

Example 16 ...The 1980s paintings and sculptures could have been omitted without diminishing the exhibition's impact. (modal);

d) turning bad into good evaluation (ambivalence): 
(here, probably for encouraging purposes)

Example 17. While the exacting works might suggest these artists are striving toward an ideal of perfection [the exhibiting artists are students of California State University], they also reveal the hand's inevitable quirks. Accidents and imperfections - a skewed line, a messy intersection of marks - were evident, adding an imprimatur of originality to the pieces. This exhibition was a celebration of the human touch and its ability to create flawed wonders. (notice the paradox; also notice the hedging modal and the "suggest" verb);

e) ambiguity is sometimes preferable to a negative evaluation (also see Example 30)

Example 18. The thrust of his project appears to revolve around the painting process itself, an attempt to find a new way of working that would require a new way of seeing. (which does not exist, at least not for the moment; therefore, it seems difficult to understand such a work).

Another strategy of politeness suggested by Brown and Levinson is avoiding the FTA. This strategy is quite unlikely to be found in an art review proper. It still may exist in some reviews dedicated to exhibitions of great masters, recognized and established as such by art history. In this case, the only possible FTAs may refer to the exhibitions' curators and not to the great masters themselves.

Other politeness strategies are used to maintain the positive and negative face of the public. Readers of art reviews do appreciate good suggestions as to how an artwork may be interpreted and to what its value is, but no readers will enjoy being told what and how they should understand and appreciate an artwork. It is the good critic's skill to let his/her reader feel his/her equal, share in the common goal of appreciating good art. A prerequisite to good art criticism writing, and also a politeness strategy, is abiding by The Processibility Principle (Leech, 1983). This principle states that messages should be comprehensible, clear, brief, orderly, easy to process and that in the process of information, the speaker refers to what is already known to the hearer at the beginning of the utterance and predicates the new, relevant, focused information at the end. It is, still, the belief of some Romanian art critics that the more intricate and fussier and "absconded" the "message", the more interesting the writer. How should then the readers of such texts (if any) understand their attitude toward the public?

Maybe the most important device for reducing social (and expertise) distance between the writer and the reader of an art review is the use of an informal register to 
suggest a kind of talk between friends, or, sometimes, even a kind of complicity and gossip. Some other devices art critics use to handle the public's face and reduce the size of impositions of any kinds appear to be to following:

f) expressing solidarity with the reader/public:

The plural of solidarity and inclusiveness seems to best serve the reader's need to feel the critic's equal, to share the same preoccupations and values (also see Examples 5, 30):

Example 19. There are no types or diagrams here but fully formed beings with clear sensibilities that are, to us, so strange as to command our attention; Example 20. Hot Seat 2, a square canvas with a background grid of vibrant red and blue features a vaguely tower-like shape [...] We know the tower is in front of the grid - but just barely. That hot red background asserts itself aggressively and plunges our eye into a netherworld where...

g) Joking (humor) is always a splendid device to reduce social distance and bring the readers closer to the writer. In creating humorous utterances during an interaction people hint, presuppose, understate, overstate, use irony, tautology, ambiguity, etc.:

Example 21. Everyone in the drawings smokes cigarettes, sublimation being essential to survival in this bizarre world. (Besides, if the antismoking police were pointing their guns at you, you'd want that last drag, too.) - a presupposition;

Example 22. These "multimedia salads", as Oiticica called them, are meant to flicker across our consciousness, as discrete, disconnected phenomena... - irony + metaphor;

Example 23. In the end, Schnabel is a painter of splendiferous pomposity (informal humorous adjective). I left the show desperate to encounter someone with a sense of irony and lightness of touch. (final evaluation, implying what the show lacks in);

h) Play on words:

Example 24. One Clara with brilliant blue eyes has a cocoa-, or kaka-, colored brown face [...] (where "kaka" is a species of greenish and olive-brown New Zealand parrot);

k) Oral features, suggesting a continuous dialogue with the reader and reducing the social (and expertise) distance: 


\section{- $\quad$ discourse markers}

Example 25. Well, Apples and Eve attests the fire is back in full blaze;

- sharing personal feelings and emotions with the reader by using suggestive determinatives (adjectives and adverbs, just like in advertisement):

Example 26. This superb, international touring show... features Oiticica's moving and provocative "quasi-cinema" experiments...;

Example 27. This is a mature and culminating painting by an artist who has been astonishingly consistent...;

Example 28. Meticulously realistic painting...; clunky mechanics and assorted flotsam and jetsam that had been cunningly arranged to produce ethereal effects...; the most striking was... only slightly less unsettling was...; - questions (of a rhetorical character) addressed to the readers:

Example 29. Is geography destiny?

1) minimizing imposition (of own interpretations and evaluations of the artworks) by linguistic devices:

- "suggest" verbs vs. "to be":

Example 30. This seems to me a better solution than the old Italian one, for it induces an idea that is bigger than art. (notice the comparison implying that from two bad things the critic has chosen the lesser one; meanwhile the implicature of the ambiguity here is that, in spite of the highly philosophical meanings of the works, we are not really dealing with good art);

Example 31. The imagery alludes to many kinds of meaning, without being restricted to a particular iconography...;

Example 32. I would suggest rather that her achievement has been to recover the dignity which they were already given...

Also see Example 15. I want to suggest that....

- impersonal expressions:

Example 33. In the eleven-by-fourteen drawings recently on view, one can recognize a population of regulars that include superheroes...;

Example 34. The East Village scene of the early '80s, one could argue, was as much a state of mind as a place...;

Example 35. Initially, it appears that the textile is Gottlieb's primary source. But then it becomes apparent that the static design of the fabric lacks the 
sense of movement and depth that Gottlieb achieved on canvas. (also notice the 'suggest' verb “appears");

Example 36. You get a sense that certain recurrent colors and motifs in these paintings possess a symbolism to which only the artist has the key. It's hard to know whether S... wants to invite you in or keep you out of his mysterious goings-on. In the meantime, as you try to make up your mind, the striking palette and stylized figures are more than sufficient to hold your attention. (where "you" = anybody);

m) minimizing imposition by offering evidence from the work itself.

This tool is widely used in any good art review. A good art critic always seeks to offer his/her reader evidence to support his/her interpretations of certain aspects of the artworks or the whole meaning of an artwork. It is the reader's privilege to decide whether or not s/he accepts a specific interpretation supported by the proof taken from the work itself and it is also the reader's privilege and right to feel free to give that specific aspect any other interpretation if $\mathrm{s} /$ he finds other proofs in the work.

Example 37. In an untitled diptych from 1998, Borysewicz has sketched a head devoid of features...The outlined head bridges the two horizontal panels of the painting, whose only other details are a fleur-de-lis and a solid grey circle on the bottom right. Given the spiritual tenor of this show, it was not hard to see this head, with its suggestion of long hair, as another image of Christ [...].

n) minimizing imposition by personal attribution (which is also supported by offering evidence from the work itself) The author implies that what $\mathrm{s} /$ he offers as interpretation and/or evaluation is just personal opinion and therefore the reader should feel free to discern in the artwork any other meanings and appreciate the value for himself/herself:

Example 38. For me, Point is the most realized of the figure paintings. It shows the women seen from above. The blue-white background, more than a neutral backdrop, interlocks with the figures. The depiction of the accurately-rendered, blue-jean-clad women captures Connolly's edgy method, without the clamoring distortions [...].

Also see Example 12. For me, the iconography of the piece isn't so interesting...

Also see Example 15. I want to suggest that... 
o) minimizing imposition by appealing to other recognized authors Example 39. In Huang's paintings, we are dealing with the numinous, which, as theologist Rudolf Otto wrote, involves not only awe but anxiety - the anxiety Pascal said the empty space of the night sky aroused in him. (also notice the plural of inclusion)

p) minimizing imposition by minimizing personal merit and maximizing other people's merit:

Notice the minimization of personal merit in Example 37. by suggesting that anyone could see the same thing as the critic.

Thus, taking into consideration the face management of both the artist and the reader, the critic needs to adapt his/her politeness strategies accordingly. The examples above show that the range of such politeness strategies is extremely wide; so is the range of linguistic choices available to the critic. It is the critic's decision to address the face management politely or not quite so, depending on his/her principles in judging art as well as his/her care for the public he/she needs to guide and educate.

\section{Discussion}

The present study aimed to reveal several aspects art criticism needs to manage when dealing with negative judgment of the works of art. Since the role of criticism is that of mediating between the work of art and the public, with everything that enterprise entails, there are always several questions the critic needs to ask himself/herself when evaluating art. It is easier when the judgement is a positive one and the critic can openheartedly proclaim the value of a certain work (or body of works). The problem appears when the judgement is negative (the scale of how negative may vary).

Is the critic to keep a polite attitude, involving all the necessary discursive-linguistic mechanisms of managing the face-threatening act?

Is she/he to be mildly face-threatening? When and why exactly is the critic to be bluntly offensive? Is that really a choice?

A recent experiment conducted with the second-year UAD students as to whether they agreed or not with the bluntly negative evaluations of an exhibition (while studying the genre of the art review), led to interesting results. In spite of the fact that they are artists-to-be, therefore possible subjects to such evaluations, many of them agreed with the critic, while, obviously, more preferred to reword the impolite evaluations. 
There are a lot of aspects a critic needs to weigh upon when judging a work of art and there are a number of different science areas involved. Further research should probably reveal other psychological, sociological, philosophical, aesthetic, as well as linguistic mechanisms at work in this challenging art field.

\section{Conclusion}

Differing to a great extent from, let us say, science articles, art reviews seem to be closer to another genre mentioned by Greg Myers in what the use of politeness strategies is concerned: the genre of science popularizations. The art critic seems to situate himself, just like the writer of popularizations at half-distance between artists/researchers and readers, that is, between the esoteric and the exoteric groups (Myers, 1988). Any good author of such kind of texts has to think primarily of the audience, of the exoteric group; this means, in what politeness is involved, that the author has to avoid insulting the readers on the account of their lack of specialized knowledge, in the first place and, secondly, to try to make the readers feel part of the community while still maintaining the proper deference towards the specialized esoteric community, while still taking care to preserve the good face of the artists. Writing does not involve face-to-face communication. However, it seems to be helpful, effective, and considerate to always write with one's audience/s in mind, so that good communication should be maintained. This has necessarily to do with politeness, which should be seen as a discourse strategy employed in any kind of art criticism and any genres such as art reviews here. This aspect is of much interest in higher art education, in teaching the next generations of art critics, historians, theorists to become good specialists in the field, that is, being able to judge art according to its value and meanwhile capable to write about that consciously and convincingly. This may prove to be a fruitful step forward toward enlarging the art public and educating the public taste, while also establishing some necessary guidelines for the artists themselves.

\section{References:}

Brown, P., Levinson S. (1987). Politeness: Some Universals in Language Usage. Cambridge UP, Cambridge.

Crețiu, A.E. (2014). Discourse and Communication in Visual Arts. Cluj-Napoca: Casa Cărții de Știință. 
Dennet, D. (2013) Intuition Pumps and Other Tools for Thinking. New York: W.W. Norton \& Co. Inc.

Goffman, E. (1967). Interactional Ritual. NY: Garden City, Doubleday (quoted in Myers: 1988).

Iacob, B. (2019). A coat of many colors. Essentialism versus constructivism in recent definitions of art. Cluj-Napoca: Editura ASCR.

Leech, G. (1983). Principles of Pragmatics. London: Longman.

Myers, G. (March, 1988). The Pragmatics of Politeness in Scientific Articles. Duisburg: Linguistic Agency University.

Rehm, M., Andre E. (2005). Informing the Design of Embodied Conversational Agents by Analyzing Multimodal Politeness Behaviors in Human-Human Communication. Proceedings of the Symposium on Conversational Informatics for Supporting Social Intelligence and Interaction: Situational and Environmental Information Enforcing Involvement in Conversation. The Society for the Study of Artificial Intelligence and the Simulation of Behaviour.

Thomas, J. (1995). Meaning in Interaction - an introduction to pragmatics. London, New York: Longman.

Togeby, O., Asher, R.E. (ed.) (1993). The Encyclopedia of Language and Linguistics, IV. Oxford, New York: Pergamon Press.

Zdrenghea, M. (2002). Eroticism in Advertisements. Studia Universitatis Babes-Bolyai, Philologia, XLVII, 1-2. Cluj-Napoca.

Zdrenghea, M. (2004.a). United Colors of Benetton: Communicating with its Audience. Constructions of Identity (II). Cluj-Napoca: Napoca Star.

Zdrenghea, M. (2004.b). Propaganda Language and Advertising Slogans. Studia Universitatis Babes-Bolyai. Philologia, XLIX, 4. 